Discourse and Communication for Sustainable Education, vol. 5, pp. 3-21, 2014

\title{
Gender Equality in Public Higher Education Institutions of Ethiopia: The Case of Science, Technology, Engineering, and Mathematics
}

\author{
Robsan Margo Egne \\ University of Oslo, Norway
}

\begin{abstract}
Ensuring gender equality in higher education system is high on the agenda worldwide particularly in science disciplines. This study explores the problems and prospects of gender equality in public higher education institutions of Ethiopia, especially in science, technology, engineering, and mathematics. Descriptive survey and analytical research methods were used in the study. Subjects of the study consisted of university instructors, higher education institutions gender affairs officers, and female students. Gender-related policy documents were also used as sources of data. Questionnaire, interviews, and documents analyses were employed as tools of data collection. The data were analysed using mixed methods. The study revealed a serious underrepresentation of female students in science disciplines in the contemporary Ethiopian public higher learning institutions. The paper discusses both the core factors that discourage women from pursuing sciences and suggestions which may assist them join and succeed in sciences.
\end{abstract}

Keywords: gender equality, hard science, higher education, science education

The provision of higher education is a recent phenomenon in Ethiopia: the first higher education institution in Ethiopia, the University College of Addis Ababa, opened in 1950. Little progress was made in the expansion of higher education institutions until the introduction of the current education and training policy in 1994 (Leka, 2004). Following the adoption of an education and training policy (Federal Democratic Republic Government of Ethiopia, 1994), the Ethiopian Ministry of Education produced a document entitled "Higher Education System Overhaul", outlining the reform of tertiary education. Similar to the situation in other African countries, the reform's objectives are to ensure equality, access, accountability, relevance, and responsiveness to the demands of the Ethiopian people (Ashcroft, 2004). In particular, the reform process focuses on poverty reduction and promoting sustainable development in the country (Semela, 2006). Relevant to this reform have been the efforts to enhance gender equality and bridge the development gap between the various regional states, nationalities and other social groups by increasing access to higher education (Wondimu, 2004). 
As part of the implementation strategies for the above reforms, the Ethiopian government designed and implemented affirmative action in 1998, which aimed to promote gender equality, especially in the universities of the country. This program includes an initial orientation for all first year female students; female-only tutorials in four subjects chosen by the students during their first academic year; a guidance and counselling service led by female professional counsellors on a one-to-one basis; peer counselling and support from senior female students; academic support from capable senior female students; and overall assertiveness training (Demise et al., 2002). In addition, this affirmative action program enables females to enrol at universities with a 0.2 grade point average less than that of males.

Furthermore, in 2008, the Ethiopian Ministry of Education came up with a new policy whereby $70 \%$ of overall university enrolment is expected to be in a science field, with the remaining $30 \%$ in the social sciences. This new enrolment policy has emerged based on Ethiopia's aim to produce more graduates in the fields of science, technology, engineering, and mathematics (hereafter STEM) to secure sustainable development in the country. However, when it comes to gender equality, this new enrolment policy may further deter Ethiopian females' participation in higher education. In support of this claim, Tsegai (2010) states "the prioritization of science and technology (70:30) that was introduced in 2008 within the educational and development policies of the country may further exclude female students unless additional actions are taken to promote their participation in these fields" (p. 86). Local studies (Bekele et al., 2007; Semela, 2010) suggest that the Ethiopian higher education system in general is ineffective when it comes to addressing gender equality in all fields of study and in STEM in particular.

While there exists an extensive body of literature on female participation in STEM in the western world, little is known about the underlying reasons why women are less interested in studying STEM in an African context. Morley et al. (2006) argue that there are limited data about the underrepresentation of female staff and students in STEM in middle and low-income countries. Hence, in this article, I aim to enhance our understanding of the key factors shaping the pattern of females' low enrolment and retention in STEM subjects in Sub-Saharan Africa, using Ethiopia as a case study. To this effect, this research attempts to answer the following questions.

- Why do most female students not study STEM in the higher education institutions of Ethiopia?

- What are the strategies in place to enhance gender equality in STEM in line with the current Ethiopian higher education enrolment policy?

- Are these strategies aligned with the explanations for the STEM gender gap?

\section{Development of Science Education in Ethiopia and Female Participation}

It is important to present an overview of the development of science education in Ethiopia before discussing Ethiopian females' participations in STEM. In Ethiopia, the launch of modern, western-type secular education in 1908 is believed to have marked the inception of science education. Nevertheless, in the first few decades following the introduction of modern education, little attention was paid to the study of science in school, as the emphasis was upon the study of languages and public administration 
(Semela, 2010). However, during the reign of Haile Selassie I, science became a major component of the school curriculum, as affirmed by the opening of the Faculty of Science of the University College of Addis Ababa in 1950 (Zewde, 2002).

During the Dergue regime (1974-1991), some colleges offering diplomas in basic science disciplines, such as biology, chemistry and physics, were opened in various places in Ethiopia. In connection with the introduction of the National Democratic Revolution Program of the Dergue regime, science and technology were paid due attention based on the communist principle of shaping the 'well rounded socialist personality', though little was achieved in the education sector owing to the internal political crises and armed conflict with the opposition forces (Semela, 2010).

After the current Ethiopian government came to power in 1991, a new education and training policy, which proposed that science and technology should be one of the core aims of the national education system, was developed in 1994. To cater for the trained manpower needs of the country, a number of universities opened, offering various programs, including sciences. At present there are 32 public higher education institutions offering science education in the country.

Regarding female Ethiopian students' participation in STEM, local studies indicate a low enrolment and low retention rate in the disciplines. For instance, according to Semela (2010), in 2007/08, of the total 2208 undergraduate physics students enrolled at ten relatively well-established universities, only $175(7.9 \%)$ were female, while the number of female graduates was 29 , which accounts for only $5.7 \%$. Bekele et al. (2007) also claim that undergraduate female students' enrolment rates at Jimma University, one of the largest universities in Ethiopia, in the period 2001-2005 in the fields of pharmacy, technology, veterinary medicine, and other sciences were $2.8 \%, 3.2 \%, 3.8 \%$, and $9.8 \%$, respectively. By contrast, the enrolment rates in language studies, business and economics, and social sciences were $25.2 \%, 26 \%$, and $28.3 \%$, respectively. Furthermore, as to Semela (2010), the data gathered at the national level in 2008 by the Ethiopian Ministry of Education indicated that for every 100 higher education male students, there were only seven or eight females.

Such studies may reveal the serious underrepresentation of Ethiopian females in STEM. Yet there remains no substantial research on the factors and circumstances shaping this pattern, despite policy statements that express a commitment to promoting gender equality in Ethiopia's education system particularly in STEM subjects. Hence, this study is an attempt to find out the key factors that hinder most Ethiopian women from studying STEM like their male counterparts. Furthermore, it aims at proposing strategies which may enhance women's participations in STEM subjects.

\section{Rationale for Female Participation in STEM}

To effectively promote scientific and technological advancement, it is important to ensure the participation of women across different national economic and public sectors especially in developing countries like Ethiopia. This is because empowering women in fields of studies such as STEM that have high economic returns has a number of advantages. Such women may raise healthier families, apply improved hygiene and nutritional practices, and become productive both at home and at work, thereby improving their own life as well as that of their family. Nevertheless, many adolescents, especially female 
and minority students, choose not to pursue careers in STEM (Jacobs \& Simpkins, 2005).

Gender equality and women's empowerment are central to the achievement of the Millennium Development Goals (UNDP, 2005). It is clearly underscored in various development programs that gender equality and women's empowerment are not only just and desirable ends in themselves, but also serve as vehicles for the achievement of all of the other Millennium Development Goals (Kabeer, 2003). Coombs (1985) contends that particularly in developing countries, the education of women holds the key to all elements on which the transformation of societies depends - population control, family health, personal hygiene, nutrition, receptivity to innovations, and educational motivation of children. Despite this, according to (Osborne et al., 2003), there is a disparity between the increasing recognition of the importance and economic utility of scientific knowledge and its cultural significance on the one hand, and on the other, the declining interest of students in general and female students in particular in pursuing science. This disparity has become a matter of considerable societal concern and debate.

\section{Female Students' Enrolment and Retention in STEM}

It might be argued that any effort which is intended to increase women participation in STEM is expected to pay equal attention to their enrolment and retention. As a public good, science education is expected to be accessible to every citizen of a nation, regardless of social and other classifications. Despite this fact, gender disparities in STEM are substantial (Fox et al., 2011).

According to Rathgeber (2003), in all parts of Africa, natural sciences and engineering are systematically rejected as attractive courses of study by women. However, very little public discussion has occurred about the low number of women engaged in STEM, and no real efforts have been made by the African university administrators to establish why females reject these fields of study (Rathgeber, 2003). In Africa, far from being encouraged to study science, females are subtly - and sometimes very directly - told repeatedly by teachers, schools, universities, and the various bureaucracies that science is not a suitable area for them to study (Rathgeber, 2003; Woodhouse \& Ndongko, 1993).

As to Rathgeber (2003), this attitude tends to be replicated in the workplace. Relatively few African women hold senior academic positions in science-related subjects. This means that females who wish to pursue science have few mentors and role models. Oanda and Akudol (2010) further claim that not only are there fewer female SubSaharan African students enrolled in STEM, but also that their completion rates are lower compared to those of male students. Given the importance of science and technology to African development, this issue demands serious attention from the policymakers.

\section{Key Factors that Shape Females' Choice of STEM}

Many researchers who have attempted to understand why females underrepresented in STEM have suggested widely divergent explanations (Blickenstaff, 2005; Brotman \& Moore, 2008; Hsu et al., 2009; Taylor et al., 2001). Nevertheless, in this study, the core factors (lack of ability, absence of awareness, gendered nature of STEM i.e. considering STEM as masculine subjects, lack of female-friendly environment, and inadequate sup- 
ports from universities) that are assumed to influence most females' possibility of studying STEM are emphasized.

\section{Lack of Ability or Lack of Academic Preparation}

To join and succeed in STEM at university level, it is important for female students to prepare themselves academically from an early stage. According to Taylor et al. (2001), a student decides to become a scientist between fourth and six grades. This means that disadvantaged learners particularly females and minorities, need early interventions to motivate them to continue to study science subjects.

A number of studies suggest that in the early grades there is no significant difference between girls and boys with respect to interests in science (Baram-Tsabari \& Yarden, 2011; Barton et al., 2008; Francis, 2000a). However, the interests of girls in science fall considerably behind those of boys as they progress through the grades (Barton et al., 2008; Christidou, 2011; Dawson, 2000; Evans et al., 2002). As to Sadker et al. (1997), starting from the middle school level, girls say that mathematics and science are less important and useful with respect to their career. As a result, the majority of them start college without completing four years of high school mathematics adequately. This lack of preparation serves as a 'critical filter', inhibiting most girls from entering many careers in STEM. In a similar way, most Ethiopian females loose interest in science as the grade levels increase (Zeleke, 2005).

Generally, the above notions imply that, to help Ethiopian women to enter and succeed in STEM, it is important to pay special attention to their science ability starting from the lower grades in general and in the middle grades in particular. In support of this argument, Barton et al. (2008) claim "the middle grades are a crucial time for girls in making decisions about how or if they want to follow science trajectories" (68). Similarly, drawing on Evans (1965), it could be argued that early success, resulting from ability, may give rise to interest, which in turn, leads to persistent effort, and this combined with ability is likely to culminate in success. Furthermore, according to Wyss et al. (2012), very often, students make choices in middle school that will impact their desire and ability to pursue STEM careers. Overall, the above discussions reveal the fact that there is a need for changing the way science is taught in the lower grades especially in the middle and high school levels in order to enable female students to join and succeed in STEM fields of studies at university level.

\section{Absence of Awareness}

Having a clear perception of what a field of study has to offer students may have a great bearing on their decisions in educational stream choice thereby making career choices. Many studies (Sadker et al., 1997; Tai et al., 2006; Wyss et al., 2012) suggest that students make decisions about their future career choices at the middle school level. This, in turn, may imply the fact that unless female students have adequate information about STEM as both a field of study and a career; they may join other fields of studies such as social sciences while they still have all it takes to join and succeed in STEM subjects. Concerning this claim, Wyss et al. (2012) assert that 
In an effort to increase the number of students who will pursue STEM study and careers, we need to increase student awareness of a variety of STEM careers early on. Students who are offered this information in school will be better able to make informed decisions about their interest in STEM and better prepare for those careers (p. 504).

Having a clear awareness about STEM may have a far reaching impact on whether women pursue it as a field of study particularly in developing countries such as Ethiopia where there is a limited possibility for students to get adequate information about the discipline they want to pursue. This lack of awareness may make a student join the social science while his/her performance is still good in hard science. This suggests the importance of raising the awareness of female students long before they make their educational stream choices.

\section{Views of Females (STEM is Gendered)}

One of the key factors that may affect female students' science career aspirations and identities is the students' self-efficacy (Glynn et al., 2007; Post et al., 1991). This means that women's self-concept and how they regard other people's perceptions of their ability may influence their educational stream choice. According to Francis (2000b), traditionally, 'the sciences', such as mathematics, science, and information technology, have been perceived as a masculine domain while, conversely, 'the arts', like languages, arts, and the humanities, have been constructed as feminine. This dualistic allocation carries a hierarchy in terms of subject status: 'the sciences' are associated with highstatus traits, such as rationality and objectivity, while 'the arts' are associated with emotion and subjectivity. It is the construction of these traits as gendered which usually lead to the assignment of these subjects as either masculine or feminine (Hedlin, 2011). The same factors and experiences apply in Ethiopia regarding women's relationships to STEM. In support of this claim, the Ethiopian Ministry of Education (2009) ascertains the fact that Ethiopian females are underrepresented in STEM unlike their relatively better representation in business and economics, education, law, and health sciences.

Furthermore, according to Morley et al. (2006), there is a perception that, if a subject is 'hard', then it is unsuitable for women. The hard/soft binary thinking around academic subjects is gendered. The challenge is for women to push through what is socially accepted as 'hard'. In such a context, even capable females who can perform well in STEM may study the arts simply just to conform to the prevailing norm. Hedlin (2011, p. 449) claims that students' ongoing identity formation is of great significance with regard to how they relate to different fields of knowledge.

\section{Educational Experiences Less Accessible to Females (Not Female-friendly)}

It could be argued that the educational experiences that females encounter in science education may have a bearing on whether or not they participate in STEM. In this regard, the examples and illustrations women's experience in science classes and curricula, the teacher-centered, male-dominated mode of science education, etc., may negatively affect their inclination towards STEM. Supporting this claim, Sadker et al. (1997) state that "misrepresentations and omissions can negatively affect the self-image, goals, and philo- 
sophy of girls” (p. 134). According to Christidou (2006), to foster students' interests in science, the topics taught in schools should be selected with great care. To this end, it is important to revise the existing science curricula in order to incorporate those topics which are of interest as well as relevance to the students especially for female students.

Moreover, women need positive role models for the development of positive selfesteem. Role models particularly female role models influence female students to choose sciences as field of studies as well as careers in STEM (Christidou, 2011; Evans et al., 1995; Snowman \& Biehler, 2006; Wallace \& Haines, 2004).

Taylor et al. (2001) assert that the application of three important models i.e. equitable teaching strategy, inquiry-based learning, and cooperative group learning may help females to pursue STEM disciplines. In other words, through equitable teaching strategy attempts are made to meet the educational needs of females and minority students in order to empower them to pursue science subjects whereas inquiry-based instruction aims at encouraging underserved students such as female students to ask critical questions and find answers through problem-solving technique. Cooperative group learning, on the other hand, may foster theme works whereby students learn from each other through reflection and experience sharing. Such practices may empower female students to enter and succeed in STEM subjects like their male counterparts.

By the same token, the use of student-centered learning experiences and teaching methods in Ethiopian science education, where females receive individualized support, apart from participating in cooperative learning, may encourage them to participate and succeed in STEM. Further, the use of gender-fair materials may encourage women to enter and succeed in science education. In sum, in order to attract Ethiopian women towards STEM, it is important to make science education female-friendly.

\section{Lack of Adequate Support from Higher Education Institutions}

Higher education institutions are expected to orient and guide students, especially disadvantaged learners, in their educational stream choice. If students are to make wise field of study choices, there is a need for orientation and guidance before as well as during the choice process by the body responsible. This means that, students particularly underserved learners are expected to be guided into those educational channels that are assumed to have better prospect and return. Furthermore, universities are expected to deliver sustainable supports especially for underserved students in order to help them complement their studies. To this end, it is important to deliver sustainable trainings especially for science teachers on how to plan, deliver and assess lessons in a studentcentred manner. This strategy may motivate women to enter STEM subjects like their male counterparts.

Despite this fact, according to Semela (2010), Ethiopian university officials deter females from studying the hard sciences as an "affirmative action", imagining that this strategy will help to minimize the dropout rate for female students. Semela (2010) further claims that Ethiopian women's possibility of participating in the hard sciences in general and the physical sciences in particular is mainly discouraged at the Ethiopian higher education institutions' level. The paradox is that, as a matter of regulation, $30 \%$ of the total enrolment in all STEM subjects is reserved for female students. Of the remaining $70 \%$, male and female students compete based on their Ethiopian National Higher Education Entrance Examination grades. According to this formula, in the science field, 
the majority of females students study biology and the remaining few study chemistry. Very few study the other sciences.

Similarly, Wondimu (2004) asserts that the Ethiopian higher education institutions' officials and teachers are unconvinced of the need for affirmative action. As a result, they do not provide the necessary academic and material support for female students as outlined in the affirmative action program. This shows that, instead of helping females to study and succeed in STEM, the Ethiopian higher education institutions downplay the implementation of the gender affirmative action program.

\section{Strategies for Enhancing Female Students' Participation in STEM}

Local studies (Semela, 2010; Wondimu, 2004) suggest that Ethiopia's higher education institutions do not seem to be effectively implementing gender parity strategies. Nonetheless, many studies in other African countries reveal that their universities are successfully implementing their gender equity strategies, especially in STEM. For instance, according to Lihamba et al. (2006), at the University of Dar es Salaam, three major strategies have been used as affirmative action to increase women enrolment in the sciences. They are the Pre-entry Program, Preferential Admission Criteria and Scholarship Program. The objectives of the Pre-entry Program have been to increase the number of females in the sciences and thus increase the number of female A-level science teachers in the country. To that end, remedial courses are provided for women who have not attained the minimum academic requirements to enter the faculty of science at the university. Accordingly, those who pass the entry examination will have a chance to study STEM.

The central purpose of the Preferential Admission Criteria is to facilitate the admission of qualified female applicants to all faculties but with lower A-level grades and matriculation points than the male applicants. Hence, this strategy has been found to be effective in increasing female admissions to the University of Dar es Salaam, especially in the field of the sciences. The third strategy i.e. the Scholarship Program is intended to support needy and deserving women to pursue their studies at both the undergraduate and postgraduate levels in all fields. As to Lihamba et al. (2006), this program has been effective in attracting women to study STEM. Above all, these three strategies have stimulated a culture of responsiveness to gender equality in the university's enrolment process.

The research conducted by Kwesiga and Ssendiwala (2006) on gender equity at Makerere University also revealed the effectiveness of giving additional points to females to raise their entry to the sciences. In addition to this strategy, using scholarship to increase female enrolment in STEM was found to be successful. Gender mainstreaming, whereby attempts are made to bridge gender gaps in diverse aspects of university life, was also found to be effective in promoting gender equality in the sciences at Makerere University. In addition, Shackleton et al. (2006), through the research they conducted on gender equity in the South African universities, suggested the need for the overall transformation of the work culture and attitudes of all of the actors involved in the implementation of gender equity in STEM especially in engineering.

To sum up, the foregoing discussion highlights the existence of variations among the African universities in terms of implementing strategies to enhance women participations in STEM. It could be argued that countries such as Ethiopia may learn a lot 
from other African countries whose universities have succeeded in fostering gender equality in STEM.

\section{Methodology}

This research is a case study through which attempts are made to gain a better understanding about the core factors that deter most Ethiopian women from studying STEM. To this effect, two public universities, i.e. Addis Ababa University and Adama Science and Technology University, which have relatively well-established systems particularly in STEM, were used as samples purposely. These universities were selected due to the fact that they have a relatively better institutional capacity for implementing gender equality in STEM. This, in turn, is assumed to be useful for judging the extent to which the other public universities, with less capacity, might implement gender parity in STEM.

The data sources were female students, heads of the gender offices, and selected instructors from the two universities. Moreover, gender-related policy documents were also used as sources of information. Both STEM major and social science major third year female undergraduate students were taken as the target of the study. According to the current Ethiopian university education policy, most social science major students finish their undergraduate studies at the end of their third year. So, third year female students were targeted, taking their seniority and level of maturity into account. The assumption was that the data gathered from such students were most likely to yield better results because these students are more mature and able to discuss their circumstances.

Data were gathered using questionnaires, interviews and documentary analysis. A questionnaire was used to gather data from female students at the two universities. The items on the questionnaire were both closed-ended and open-ended. The former were prepared in a Likert-scale with five options (strongly disagree, disagree, undecided, agree, strongly agree) with the intention of obtaining objective responses through ensuring relatively better flexibility in the checking of each item, whereas the latter gave the respondents full freedom to express their feelings. In the closed-ended items, each of the five core factors (lack of ability, absence of awareness, gendered nature of STEM, lack of female-friendly environment, and lack of adequate support from universities) that may deter women from studying STEM was systematically repeated twice to check the consistency of the respondents' responses. Thus, the first and sixth items were framed based on lack of ability, the second and seventh items were set based on absence of awareness, the third and eighth items were prepared in line with gendered nature of STEM, the fourth and ninth items were designed to address lack of female-friendly environment whereas items number five and ten were framed to analyse whether Ethiopian universities provide adequate supports to females in order to help them complete their studies (Table 1).

After preparing the questionnaire, a pilot study was undertaken. In this regard, the questionnaire was administered to a sample consisting of 160 (half STEM majors and half social science majors) female students, randomly selected from the universe of the study. The appropriateness of the items on the questionnaire, i.e. whether they solicit the intended data and the intelligibility of the wording, was judged based on the responses of the respondents and then improvements were made accordingly. Finally, the questionnaire was administered to 380 sample female students that were taken from the two 
streams to compare their opinions. STEM students were included in the sample, although they have already chosen STEM as their major, so they may explain why they are still there. Out of the total respondents, 320 filled out the paper questionnaire correctly and returned it, i.e. with the response rate of $84.21 \%$.

To obtain additional information to the data provided by the respondents on the questionnaire, semi-structured interviews were conducted as tools of data collection with the heads of the gender offices of the universities, two instructors (one from each university), and four female students (two from each university) selected using purposive sampling technique.

The questionnaire and interview questions were designed in a way in which they complement each other. In other words, the content of the interviews followed that of the questionnaire, and thus was crosschecked with the questionnaire responses. In general, the contents and focuses of the questionnaire and interviews emphasized the five key factors that shape women inclinations towards STEM subjects.

The quantitative data collected through the closed-ended items on the questionnaire were computed using percentages. In so doing, the five-point scale was reduced to a three-point one to make the data tabulation process more intelligible in terms of presenting the results concisely. To this end, the values for 'fully disagree' and 'disagree' were combined, as were those for 'agree' and 'fully agree', while the values for 'undecided' were treated separately. Therefore, the forthcoming results and discussion is based on the three-point scale table. Nevertheless, the data gathered using the open-ended questionnaire items, interviews, and documentary analysis were analysed qualitatively. Generally, mixed methods (Creswell, 2014; Creswell \& Plano Clark, 2011) were employed in analysing the data.

Regarding the research ethics, before the necessary data were collected from the respondents and informants, they were informed about the research objectives and procedures to be followed, and their consent was obtained. Further, anonymity was maintained throughout the research activities.

\section{Results and Discussions}

In this section, the data gathered from the questionnaires, interviews and documentary analysis are presented and analysed.

Table 1

Female Students' Responses to the Closed-Ended Items of the Questionnaire $(n=320)$

\begin{tabular}{|c|c|c|c|c|c|c|c|c|}
\hline & \multirow{3}{*}{ Items } & \multirow{3}{*}{$\begin{array}{l}\text { Respondents' } \\
\text { field of studies }\end{array}$} & \multicolumn{6}{|c|}{$\begin{array}{l}\text { Proportion of female students } \\
\text { in each category }\end{array}$} \\
\hline & & & \multicolumn{2}{|c|}{ Disagree } & \multicolumn{2}{|c|}{ Undecided } & \multicolumn{2}{|c|}{ Agree } \\
\hline & & & $\mathrm{N}$ & $\%$ & $\mathrm{~N}$ & $\%$ & $\mathrm{~N}$ & $\%$ \\
\hline 1 & 2 & 3 & 4 & 5 & 6 & 7 & 8 & 9 \\
\hline \multirow[t]{2}{*}{1} & \multirow{2}{*}{$\begin{array}{l}\text { Most Ethiopian higher education } \\
\text { institutions' female students do not } \\
\text { pursue science, technology, engi- } \\
\text { neering, and mathematics due to } \\
\text { inadequate preliminary knowledge. }\end{array}$} & STEM major & 24 & 15 & 12 & 7.5 & 124 & 77.5 \\
\hline & & $\begin{array}{l}\text { Social science } \\
\text { major }\end{array}$ & 10 & 6.25 & 6 & 3.75 & 144 & 90 \\
\hline
\end{tabular}


Sequel to Table 1.

2 I had got adequate awareness about the field of study I'm pursuing now long before I joined this university.

\begin{tabular}{lcccccc} 
STEM major & 12 & 7.5 & 4 & 2.5 & 144 & 90 \\
\hline Social science & 16 & 10 & 8 & 5 & 136 & 85
\end{tabular}
major

3 I feel most Ethiopian female students do not join hard sciences because of poor self-concept.

\begin{tabular}{lcccccc} 
STEM major & 28 & 17.5 & 12 & 7.5 & 120 & 75 \\
\hline Social science & 12 & 7.5 & 8 & 5 & 140 & 87.5
\end{tabular}
major

4 I think the existence of limited number of female instructors in hard sciences makes most female students \begin{tabular}{lllllll} 
STEM major & 32 & 20 & 12 & 7.5 & 116 & 72.5 \\
\hline
\end{tabular} not to join the fields.

5 My university is making all its best to make the learning environment favourable for female students in \begin{tabular}{lllllll}
\hline Social science & 16 & 10 & 6 & 3.75 & 138 & 86.25
\end{tabular} major relation to 'the $70 \%$ science and $30 \%$ social science program' in order to help them complete their studies.

\begin{tabular}{llllclcll}
\hline 6 & Most Ethiopian female students show & STEM major & 32 & 20 & 8 & 5 & 120 & 75 \\
\cline { 2 - 7 } & little interest towards hard sciences & Social science & 20 & 12.5 & 4 & 2.5 & 136 & 85
\end{tabular}
due to lack of academic preparation major starting from the lower grades.

7 I have got a clear understanding of the differences between social and natural science field of studies starting from the lower grades.

\begin{tabular}{lcccccc} 
STEM major & 128 & 80 & 14 & 8.75 & 18 & 11.25 \\
\hline $\begin{array}{l}\text { Social science } \\
\text { major }\end{array}$ & 136 & 85 & 8 & 5 & 16 & 10 \\
& & & & & &
\end{tabular}

\begin{tabular}{lllllllll}
\hline 8 & $\begin{array}{l}\text { Most Ethiopian female students do } \\
\text { not join hard sciences because of }\end{array}$ & STEM major & 40 & 25 & 12 & 7.5 & 108 & 67.5 \\
\cline { 2 - 7 } & Social science & 24 & 15 & 4 & 2.5 & 132 & 82.5
\end{tabular} their threating nature. major

\begin{tabular}{lllllllll}
\hline 9 & The way through which hard sciences & STEM major & 40 & 25 & 16 & 10 & 104 & 65 \\
\cline { 2 - 8 } are taught in schools makes most & Social science & 16 & 10 & 8 & 5 & 136 & 85
\end{tabular}
Ethiopian females not to join them as major fields of studies.

10 The sustainable supports that I have got from my university in connection to 'affirmative action program' helped me to succeed in the subject I'm studying now.

Source: Survey data

Note: $\mathrm{n}=$ number of respondents

In the table above, the first item deals with the question of whether most female Ethiopian students fail to engage in STEM due to inadequate preliminary knowledge. Regarding this, $77.5 \%$ of the female STEM major and $90 \%$ of female social science major agreed with the statement. Furthermore, $75 \%$ of STEM major and $85 \%$ of social science major said that most Ethiopian female students show little interest towards hard sciences due to lack of academic preparation starting from the lower grades. This means that most of the respondents from the two universities think that most Ethiopian women do not study STEM due to lack of ability. 
This, on the other hand, raises another question, i.e. why do the majority of STEM female respondents agree that a lack of ability prevents most women from studying STEM? This might be due to the respondents thinking that the number of female students in STEM is negligible compared to that studying social sciences and/or they might consider themselves as having adequate background knowledge that helped them to study STEM, despite the existence of this problem. According to Zeleke (2005), students who are not equipped with a sound knowledge of mathematical concepts in the lower grades will certainly struggle greatly when studying mathematics and related courses in later grades.

Furthermore, in response to the interview question, 'Why didn't you study a hard science?', a female social science major commented "I am not very good at doing calculations. So, I didn't dare to study one of the disciplines that require such ability. In short, I am not a person meant for hard sciences."

On the other hand, a STEM major, when asked 'Why did you choose science as your field of study unlike the majority of Ethiopian female students?' commented: "I chose science because of my good background in the discipline. I really like mathematics and physics, starting from the lower grades so I haven't been influenced by the rumour I heard about the difficulty of the field I'm studying now."

The above two responses show how much the students' background affects their decisions when choosing which subject to study at university. In connection with this argument, Charles (2011) claims that "career aspirations are influenced by beliefs about ourselves, i.e. what am I good at and what will I enjoy doing” (p. 25).

Another female social science major student, when asked 'If you had been offered a scholarship to study hard sciences at university, would you have done so?', commented "no, I wouldn't. I know I'll benefit from the scholarship, but I was not ready to pursue such disciplines, starting from the lower grades." The above response may indicate the long trajectory that either paves or blocks the way for females to participate and succeed in STEM. As such, the decision to pursue STEM as an educational stream starts while the students are still at secondary school.

In response to the statement, 'I had got adequate awareness about the field of study I'm pursuing now long before I joined this university', 90\% of the STEM majors and $85 \%$ of the social science majors (see Table 1 above) agreed. Similarly, $88.75 \%$ of the STEM majors and $78.75 \%$ of the social science majors reported that they have got a clear understanding of the differences between social and natural science field of studies starting from the lower grades. This implies that 'lack of awareness' is not deterring most female Ethiopian students from studying STEM subjects. The social science majors might have agreed with this statement due to the fact that they had got the awareness that STEM subjects are not suitable to them so that they joined social science subjects based on their awareness.

Concerning self-concept, $75 \%$ of the STEM majors and $87.5 \%$ of the social science majors thought that the majority of female students avoided studying hard sciences because of a poor self-concept. In addition, $67.5 \%$ of STEM major and $82.5 \%$ of social science major respondents agreed that most Ethiopian female students do not join hard sciences because of their threating nature. Here, the STEM majors might have responded similarly to the social science majors, due to the fact that, unlike the majority of Ethiopian females, they might have the self-confidence to study STEM and/or they might have got such opinion due to their experience and knowledge about the problem. 
Generally, the responses of the sample female students revealed that most female Ethiopian students do not pursue STEM due to a poor self-concept about their expectation of succeeding in the field. According to Morley et al. (2006), a fear of mathematics is often reported by students and academics as a reason for many females' reluctance to study STEM. Mathematics is a powerful educational filter or gatekeeper to the sciences that remains gendered in many societies.

Furthermore, the same table examines whether or not the existence of limited number of female instructors in hard sciences deters most females from studying these fields. Accordingly, $72.5 \%$ of the STEM majors and $86.25 \%$ of the social science major respondents indicated that they think that a lack of female role models in STEM subjects affects most Ethiopian females' inclination to study this field. Similarly, 65\% of the STEM majors and $85 \%$ of the social science majors reported that the way through which hard sciences are taught in Ethiopian schools makes most females not to join them as fields of studies. The STEM majors might have developed such an opinion due to the fact that they study the discipline regardless of this problem because of their prior experience as well as ability in STEM and/or they might have taken into account what the majority of female students feel regarding the impact of the absence of female-friendly approach in the teaching of science in the Ethiopian context. Semela (2006) argues that "there are abundant theoretical and empirical supports regarding the positive effect of women role models on young female students to follow in their footsteps in all spheres including succeeding in tertiary institutions" (p. 84).

In general, this means that the educational experiences of Ethiopian female students are not female-friendly, as they are designed in many respects for males. With regard to this notion, in response to the interview question, 'Why didn't you choose one of the pure sciences when you started at university?', a social science major responded "I think such fields of study require lots of hard work, especially in laboratories. I think that such work isn't female-friendly. I even think that science instructors favour male students."

In response to the interview question 'How do you think that STEM instructors could improve female students' participations in their classes?', one instructor commented "teachers who teach sciences should be equipped with the ability and skills to use active learning in their respective courses. This, amongst other things, will enable the teachers to provide individualized support, particularly for female students."

In response to the opinion 'my university is making all its best to make the learning environment favourable for female students in relation to the $70 \%$ science and $30 \%$ social science program in order to help them successfully complete their studies,' $80 \%$ of the STEM majors and $85 \%$ of the social science majors responded negatively (see Table 1 above). Furthermore, $87.5 \%$ of STEM major and $82.5 \%$ of social science major respondents reported that they have not got sustainable supports from their respective university in connection to 'affirmative action program'.

However, the question arises: why do the STEM majors share a similar opinion with the social science majors? This might be because they have already got all what it takes to study and succeed in STEM despite the absence of a conducive learning environment in Ethiopian universities and/or they might have placed themselves in the shoes of the majority of women regarding STEM as an educational stream choice. Generally, the above notions may show that absence of a well-established, gender-based strategy in Ethiopian higher learning institutions is one of the factors that deters the majority of women from studying hard sciences. 
In response to the interview question 'What do you think is the core problem with the strategy employed in Ethiopian universities to create gender equality in the hard sciences?', one instructor commented:

First of all, I do not think that there is a specific strategy to increase the participation of female students in the sciences. But the core problem of the current gender affirmative action program is the incompatibility of the time at which the students actually choose their fields of study and when the support is provided. Students choose their major at the end of their general education (at the end of grade 10), i.e. before they start university, whereas the support services are provided during the first year of university study.

In addition, when asked the question 'What strategies could be used to improve the participation of female students in STEM?', one head of the gender office stated "gender issues should be given due attention at the various educational levels particularly in university administration. The administration should pay special attention to females' participation in the sciences by designing strategies that attract females to the disciplines." Moreover, when asked 'What do you regard as the role of the gender office in promoting female students' participation in STEM in Ethiopian universities?', one gender officer responded "except for the conventional affirmative action introduced some years ago, there is no specific strategy in use for fostering female students' participation in the sciences in the current Ethiopian higher education institutions' context." The above responses illustrate the absence of a clear strategy to enhance female students' participations in STEM, in line with the 70\% STEM and 30\% social science university enrolment policy of Ethiopia.

When it comes to the results for the open-ended questionnaire items, in response to the question 'Why do you think that the majority of female Ethiopian students show little interest in studying the hard sciences?', most of the respondents reported a lack of ability and readiness starting from the lower grades, a poor self-concept, socio-cultural gender stereotypes, and the lack of a concrete support system in the higher learning institutions. In addition, 'What strategies could be used to attract female students to study the hard sciences?' was the other core question asked on the open-ended part of the questionnaire. In response to this question, the respondents noted raising the awareness of female students, creating a conducive learning environment for female students, raising the gender awareness of STEM instructors to help them treat female students fairly, and arranging sustainable awareness raising program for the entire university community as key strategies.

Furthermore, the analysis of the higher learning institutions' policy documents revealed the existence of rules and regulations concerning the harassment and violence of female students together with other rules and regulations. Nevertheless, there is no strategy incorporated into the documents to attract female students to study STEM in line with the current university enrolment policy in Ethiopia. This, in turn, suggests that, let alone aligning the strategies with the explanations for the STEM gender gap, there is no strategy in place for enhancing females' participations in STEM in the contemporary Ethiopian universities. 


\section{Summary and Conclusions}

Ethiopia, like the other developing nations in the world, wishes to promote its sustainable development, particularly via science education. To realize this objective, the role of the universities in producing and supplying trained manpower for the different sectors, especially STEM, is decisive. Ensuring sustainable development without the participation of women in the various sectors of STEM is likely to be impossible. In this regard, if possible, it is important to avoid gender disparity or, failing that, to minimize the gap.

However, this study revealed that there is a wide gender gap between students' participations in STEM in contemporary Ethiopia. That means that most women are reluctant to study STEM even though the current university enrolment policy of the country more than ever favours these fields of studies.

The prominent factors which lead to the general lack of interest in the hard sciences among most females are their inadequate preliminary knowledge and academic preparation, their poor self-concept, the persistent effects of socio-cultural gender stereotypes, the existence of science educational experiences that do not welcome women, and the absence of adequate support systems in the Ethiopian universities. Further, the study revealed that there is no strategy in place for increasing the participation of females' in STEM in Ethiopian universities. In other words, apart from the affirmative action program introduced in 1998, no new strategy has been introduced to increase the participation of women in STEM in connection to the introduction in 2008 of the $70 \%$ STEM and $30 \%$ social sciences university enrolment policy.

Hence, to improve the participation of women in STEM, early intervention is important. To this end, it is necessary to improve the background and capacity of female students particularly in the sciences, beginning from the lower grades. To do so, amongst other things, assigning competent teachers who can effectively teach sciences at the lower grade levels is very important. Moreover, to improve the self-concepts of females, amongst other things, it is important to design the textbooks of the sciences in gendersensitive manner (Dawson, 2000). Furthermore, it is important to use strategies like providing scholarships or financial subsidies to competent but needy female students to attract them to study STEM. To promote this scholarship program, it is important to work in collaboration with fund raising organizations such as the Carnegie Foundation, the Swedish International Development Agency, and others that finance female students' education.

In addition, it is relevant to design a system in which female students can attend bridging courses that can compensate for their high school science background, particularly in mathematics, before starting university. This strategy may encourage females to study STEM. Moreover, after the students start to study STEM, in addition to what they learn on the regular program, it is advisable to provide them with enrichment courses. The bridging courses together with the supplementary courses will serve as scaffolding, particularly for those female students who start to study STEM with the minimum requirements to finish their studies. In addition, it is wise to arrange training which focuses on life skills education in general and coping skills in particular side by side with the other courses.

Furthermore, it is important to establish a concrete support system to train, orient, guide, and regularly counsel female students, especially those who study STEM, to believe 
in their talents and ability, and develop positive self-concepts. To this end, it is important to improve the awareness and attitude of the university officials and instructors through organising sustainable training programs which focus on changing the existing work into conducive learning environment.

Lastly, at the classroom level, it is important to transform the present teachercentred mode of delivery of courses into an interactive learning environment (Kelly, 2000). In particular, it is crucial to train STEM teachers on how to create conducive learning environment for female students such as treating them in a friendly manner and addressing different learning styles. Moreover, it is advisable to raise the awareness of science instructors on how to make laboratory procedures more student-friendly so that female students can participate on an equal footing with their male counterparts. The above suggestions may also have implications to reduce gender disparity in other fields of studies.

\section{Acknowledgments}

I am indebted to Professor Eileen Raymond (State University of New York at Potsdam) for commenting on the early draft of this article. I would also like to thank Professor Dorothy Edith Smith (University of Victoria, Canada) and Dr. Lela Kvinikadze (Ivane Javakhishvili Tbilisi State University, Georgia) for their constructive feedbacks. The respondents as well as the informants who provided me with the data also deserve acknowledgment. I also thank Dr. Tito Correa for making a final proofreading of the manuscript.

\section{References}

Ashcroft, K. (2004). The massification of higher education: A comparison of the UK experience and the emerging Ethiopian response. The Ethiopian Journal of Higher Education, 1(1), 21-40.

Baram-Tsabari, A., \& Yarden, A. (2011). Quantifying the Gender Gap in Science Interests. International Journal of Science and Mathematics Education, 9(3), 523-550.

Barton, A. C., Tan, E., \& Rivet, A. (2008). Creating hybrid spaces for engaging school science among urban middle school girls. American Educational Research Journal, 45(1), 68-103.

Bekele, A., Melesse, K., Mikre, F., Chibsa, G., \& Nemeta, M. (2007). Retrospective analysis of the academic status of female students in Jimma University main campus: From 2001 to 2005. Ethiopian Journal of Education and Sciences of Jimma University, 3(1), 23-42.

Blickenstaff, J. C. (2005). Women and science careers: Leaky pipeline or gender filter? Gender and Education, 17(4), 369-386.

Brotman, J. S., \& Moore, F. M. (2008). Girls and science: A review of four themes in the science education literature. Journal of Research in Science Teaching, 45(9), 971-1002.

Charles, M. (2011). What gender is science? Contexts, 10(2), 22-28.

Christidou, V. (2011). Interest, attitudes and images related to science: Combining students' voices with the voices of school science, teachers, and popular science. International Journal of Environmental and Science Education, 6(2), 141-159. 
Christidou, V. (2006). Greek students' science-related interests and experiences: Gender differences and correlations. International Journal of Science Education, 28(10), 1181-1199.

Coombs, P. H. (1985). The world crisis in education: The view from the eighties. Oxford: Oxford University Press.

Creswell, J. W. (2014). Research design: Qualitative and quantitative, and mixed methods approaches ( $4^{\text {th }}$ ed.). Los Angeles, Calif.: Sage.

Creswell, J. W., \& Plano Clark, V. L. (2011). Designing and conducting mixed methods research (2 ${ }^{\text {nd }}$ ed.). Los Angeles: Sage.

Dawson, C. (2000). Upper primary boys' and girls' interests in science: Have they changed since 1980? International Journal of Science Education, 22(6), 557-570.

Demise, A., Shinebaum, R., \& Melesse, K. (2002). The problems of female students at Jimma University, Ethiopia, with some suggested solutions. The Ethiopian Journal of Health Development, 16(3), 257-266.

Ethiopian Ministry of Education. (2009). Education statistics annual abstract (2007/ 2008). Addis Ababa: Ministry of Education.

Ethiopian Ministry of Education. (2008). Annual intake and enrolment growth and professional and program mix of Ethiopian public higher education: Strategy and conversion plan, 2009-2013. Addis Ababa: Ministry of Education.

Evans, K. M. (1965). Attitudes and interests in education. London: Routledge.

Evans, E. M., Schweingruber, H., \& Stevenson, H. W. (2002). Gender differences in interest and knowledge acquisition: The United States, Taiwan, and Japan. Sex Roles, 47, 153-167.

Evans, M. A., Whigham, M., \& Wang, M. C. (1995). The effect of a role model project upon the attitudes of ninth-grade science students. Journal of Research in Science Teaching, 32(2), 195-204.

Federal Democratic Republic Government of Ethiopia. (1994). Education and training policy. Addis Ababa: Berhanena Selam Printing Enterprise.

Fox, M. F., Sonnert, G., \& Nikiforova, I. (2011). Programs for undergraduate women in science and engineering: Issues, problems, and solutions. Gender \& Society, 25(5), 589-615.

Francis, B. (2000a). Boys, girls and achievement: Addressing the classroom issues. London: Routledge.

Francis, B. (2000b). The gendered subject: Students' subject preferences and discussions of gender and subject ability. Oxford Review of Education, 26(1), 35-48.

Glynn, S. M., Taasoobshirazi, G., \& Brickman, P. (2007). Non-science majors learning science: A theoretical model of motivation. Journal of Research in Science Teaching, 44(8), 1088-1107.

Hedlin, M. (2011). How the girl choosing technology became the symbol of the nontraditional pupil's choice in Sweden. Gender and Education, 23(4), 447-459.

Hsu, P., Roth, W., Marshall, A., \& Guenette, F. (2009). To be or not to be? Discursive resources for (dis-) identifying with science-related careers. Journal of Research in Science Teaching, 46(10), 1114-1136.

Jacobs, J. E., \& Simpkins, S. (2005). Mapping leaks in the math, science, and technology pipeline. New Directions for Child and Adolescent Development, 110, 3-6.

Kabeer, N. (2003). Gender mainstreaming in poverty eradication and the millennium development goals: A handbook for policy-makers and other stakeholders. Ottawa: International Development Research Centre. 
Kelly, J. (2000). Rethinking the elementary science methods course: A case for content, pedagogy, and informal science education. International Journal of Science Education, 22(7), 755-777.

Kwesiga, J. C., \& Ssendiwala, E. N. (2006). Gender mainstreaming in the university context: Prospects and challenges at Makerere University. Women's Studies International Forum, 29(6), 592-605.

Leka, W. (2004). Cost sharing in higher education: The international experience and the lessons to be learned. The Ethiopian Journal of Higher Education, 1(2), 17-32.

Lihamba, A., Mwaipopo, R., \& Shule, L. (2006). The challenges of affirmative action in Tanzanian higher education institutions: A case study of the University of Dares Salaam, Tanzania. Women's Studies International Forum, 29(6), 581-591.

Morley, L., Gunawardena, C., Kwesiga, J., Lihamba, A., Odejide, A., \& Shackleton, L. (2006). Gender equity in selected Commonwealth higher education. London: Department for International Development.

Oanda, I., \& Akudolu, L. (2010). Addressing gender inequality in higher education through targeted institutional responses: Field experience from Kenya and Nigeria. In S. O'hara (Ed.), Higher education in Africa: Equity, access, opportunity (pp. 6985). New York: Institute of International Education.

Osborne, J., Simon, S., \& Collins, S. (2003). Attitudes towards science: A review of the literature and its implications. International Journal of Science Education, 25(9), 1049-1079.

Post, P., Stewart, M. A., \& Smith, P. L. (1991). Self-efficacy, interest, and consideration of math/science and non-math/science occupations among black freshmen. Journal of Vocational Behavior, 38, 179-186.

Rathgeber, E. M. (2003).Women in universities and university-educated women: The current situation in Africa. In D. Teferra \& P. G. Altbach (Eds.), African higher education: An international reference handbook (pp. 82-92). Bloomington: Indiana University Press.

Sadker, M., Sadker, D., \& Long, L. (1997). Gender and educational equality. In J. A. Banks \& C. A. M. Banks (Eds.), Multicultural education: Issues and perspectives ( $3^{\text {rd }}$ ed., pp. 131-149). Boston: Allyn and Bacon.

Semela, T. (2010). Who is joining physics and why? Factors influencing the choice of physics among Ethiopian university students. International Journal of Environmental and Science Education, 5(3), 319-340.

Semela, T. (2006). Higher education expansion and the gender question in Ethiopia: A case study of women in a public university. The Ethiopian Journal of Higher Education, 3(1), 63-86.

Shackleton, L., Riordan, S., \& Simonis, D. (2006). Gender and the transformation agenda in South African higher education. Women's Studies International Forum, $29(6), 572-580$.

Snowman, J., \& Biehler, R. F. (2006). Psychology applied to teaching. Boston: Houghton Mifflin.

Tai, R. H., Liu, C. Q., Maltese, A. V., \& Fan, X. (2006). Career choice: Planning early for careers in science. Science, 312, 1143-1144.

Taylor, V. S., Erwin, K. W., Ghose, M., \& Perry-Thornton, E. (2001). Models to increase enrolment of minority females in science-based careers. Journal of the National Medical Association, 93(2), 74-77. 
Tsegai, M. (2010). Gender inequalities in the Ethiopian education system: Past trends and current status. The Ethiopian Journal of Education, 30(2), 63-98.

United Nations Development Programme. (2005). A gender review of national millennium development goals reports. Bureau of Development Office.

Wallace, J. E., \& Haines, V. A. (2004). The benefits of mentoring for engineering students. Journal of Women and Minorities in Science and Engineering, 10(4), 372-391.

Wondimu, H. (2004). Gender and regional disparities in opportunities to higher education in Ethiopia: Challenges for the promotion of social justice. The Ethiopian Journal of Higher Education, 1(2), 1-15. WOUSE

Woodhouse, H., \& Ndongko, T. M. (1993). Women and science education in Cameroon: Some critical reflections. Interchange, 24(2), 131-158.

Wyss, V. L., Heulskamp, D., \& Siebert, C. J. (2012). Increasing middle school student interest in STEM careers with videos of scientists. International Journal of Environmental and Science Education, 7(4), 501-522.

Zeleke, S. (2005). Gender difference in mathematics performance among fifth and sixth grade children in Addis Ababa. The Ethiopian Journal of Education, 25(1), 1-21.

Zewde, B. (2002). Pioneers of change in Ethiopia: The reformist intellectuals of the early twentieth century. Oxford: James Currey. 